\title{
Skala Tolerancji Wieloznaczności Edwarda F. McQuarriego i Davida Glena Micka: polska adaptacja ${ }^{1}$
}

\author{
Dominik Czajeczny ${ }^{2}$ \\ D.Czajeczny@gmail.com \\ Uniwersytet im. Adama Mickiewicza \\ w Poznaniu
}

\begin{abstract}
Celem pracy było stworzenie polskiej adaptacji Skali Tolerancji Wieloznaczności oraz jej walidacja. Grupa badawcza składała się ze 127 osób. Do badania trafności wybrano aspekt teoretyczny. Użyto następujących metod: analiza macierzy korelacji, analiza różnic międzygrupowych, analiza czynnikowa. W analizie macierzy korelacji badano związki tolerancji wieloznaczności z otwartością na doświadczenie, lękiem jako cechą, potrzebą poznawczego domknięcia oraz bezdecyzyjnością. Uzyskane korelacje wyniosły od 0,25 do 0,46. Wszystkie okazały się istotne. Inne hipotezy nie zostały potwierdzone. Analiza czynnikowa wskazuje na jednorodną strukturę skali. Skala osiągnęła alfa Cronbacha 0,68. Adaptowane narzędzie ma charakterystykę zbliżoną do oryginalnego. Głównym zastosowaniem skali są badania naukowe.
\end{abstract}

\section{Wprowadzenie teoretyczne}

W 1954 roku Eysenck (1954) pisał, że termin tolerancja wieloznaczności jest niemal sam w sobie definicją. Opisywał go w odniesieniu do pojęcia sztywności poznawczej (rigidity). W 1962 roku Budner (1962) podjął się próby analizy i zdefiniowania tolerancji wieloznaczności, a także operacjonalizacji, która umożliwiłaby stworzenie narzędzia do jej pomiaru.

W swojej pracy Budner (1962, s. 29) zdefiniował tolerancję wieloznaczności jako „tendencję do spostrzegania (interpretowania) sytuacji niejednoznacznych jako pożądanych”,

\footnotetext{
${ }^{1}$ Oryginalna skala została opublikowana przez autorów w następującej publikacji: Bruner, G. C., Hensel, P. J., James, K. E. (2005). Marketing Scales Handbook, Volume IV: Consumer Behavior. Chicago, Ill: American Marketing Association.

${ }^{2}$ Raport z badania został napisany na podstawie pracy magisterskiej „Adaptacja i walidacja Skali Tolerancji Wieloznaczności (McQuarrie i Mick)", napisanej w Instytucie Psychologii Uniwersytetu im. Adama Mickiewicza w Poznaniu. Promotorem pracy była prof. dr hab. Elżbieta Hornowska, recenzentem - prof. dr hab. Władysław Paluchowski.
} 
a nietolerancję wieloznaczności jako „tendencję do spostrzegania (interpretowania) sytuacji niejednoznacznych jako źródła zagrożenia”. Zaproponował także definicję sytuacji wieloznacznej jako sytuacji, której nie można w sposób adekwatny ustrukturalizować lub skategoryzować przez brak wystarczających wskazówek (cues). Wyróżnił też 3 rodzaje takich sytuacji: 1) sytuacja zupełnie nowa, w której wskazówki są nieznane, 2) sytuacja złożona, w której istnieje zbyt duża liczba wskazówek do przetworzenia, 3) sytuacja sprzeczna, w której wskazówki sugerują różne struktury. Są to więc sytuacje, które cechuje nowość, złożoność lub nierozwiązywalność.

Można przewidywać, że osoby różniące się poziomem tolerancji wieloznaczności różniłyby się też w swoich doświadczeniach w sytuacji niespójności, jak i w uruchamianych strategiach jej redukowania (Shaffer i Hendrick, 1974). MacDonald (1970) był zdania, że osoba o wysokiej tolerancji wieloznaczności będzie poszukiwać wieloznaczności, czerpać z niej przyjemność oraz lepiej radzić sobie z wykonywaniem wieloznacznych zadań.

Reakcje na bodźce w sytuacjach wieloznacznych zachodzą na dwóch poziomach. Pierwszy - fenomenologiczny, odnosi się do indywidualnego świata spostrzeżeń i emocji. Drugi - operacyjny, to zachowania, w tym zachowania społeczne (Budner, 1962). Osoba jednocześnie spostrzega, ocenia, odczuwa emocje i w jakiś sposób zachowuje się w odniesieniu do środowiska. Jak pisze Budner (1962), uzyskanie wskaźników z obu tych poziomów powinno umożliwić zwiększenie trafności narzędzi do pomiaru poziomu tolerancji wieloznaczności.

Budner (1962) opisał też możliwe reakcje osób o niskiej tolerancji wieloznaczności na sytuacje, które cechuje nowość, złożoność lub nierozwiązywalność. Reakcje te można podzielić ogólnie na uległość (submission) i zaprzeczenie (denial). Uległość rozumiana jest jako rozpoznanie sytuacji jako takiej, która nie może być przez daną osobę zmieniona. Zaprzeczenie - jako dokonanie pewnego przekształcenia sytuacji w taki sposób, by została dopasowana do potrzeb osoby, która się w niej znajduje. Reakcje te mogą rozgrywać się na dwóch, wspomnianych wcześniej, poziomach. Pełny podział reakcji w sytuacji wieloznacznej wygląda więc następująco: 1) fenomenologiczna uległość (lęk, dyskomfort), 2) fenomenologiczne zaprzeczenie (wyparcie, zaprzeczenie), 3) operacyjna uległość (wycofanie, unikanie), 4) operacyjne zaprzeczenie (przekształcenie sytuacji).

Występowanie wymienionych reakcji w sytuacjach wieloznacznych pozwala przypuszczać, że u danej osoby pojawiło się poczucie zagrożenia oraz, że ma ona niski poziom tolerancji wieloznaczności. 
Konstrukt tolerancji wieloznaczności jest teoretycznie bliski konstruktowi sztywności poznawczej (rigidity). Podobieństwo między nimi jest na tyle duże, że czasem oba konstrukty traktowane były jako ekwiwalentne (Eysenck, 1954). Dotyczyło to także ich pomiaru. Frenkel-Brunswick badała poziom tolerancji wieloznaczności przez określanie, do jakiego stopnia osoba utrzymywała swoją pierwotną reakcję, mimo dowodów wskazujących na jej nieadekwatność. Wybrany przez badaczkę wskaźnik jest zgodny z definicją sztywności (MacDonald, 1970).

Budner (1962) rozróżnia te konstrukty w następujący sposób: tolerancja wieloznaczności może być traktowana jako treściowa charakterystyka jednostki - tendencja do oceniania pewnych zjawisk w szczególny sposób. Sztywność - jako formalna charakterystyka jednostki - tendencja do manifestowania określonych modeli reakcji (response), bez względu na to, przez jakie zjawisko zostały wywołane.

Wieloznaczność jest czymś, czego jednostka unika lub poszukuje. Poziom tolerancji na nią jest raczej sposobem oceny sytuacji niż mechanizmem zaradczym. Jest także częścią koncepcji siebie i środowiska zewnętrznego. Z drugiej strony - sztywność może być uznana za mechanizm radzenia sobie, ale nie jest elementem koncepcji siebie i rzeczywistości. Empirycznego dowodu na odmienność tych dwóch konstruktów dostarczył Eysenck (1954), wykazując niskie korelacje między ich pomiarami, które nie uzyskały wymaganego poziomu istotności.

Tolerancja wieloznaczności jest wynikiem interakcji wielu zmiennych, jak np. percepcja, cechy osobowości, emocjonalność, wartości i postawy. Konstrukt ten jest więc złożony (Benjamin, Borst, Akkermans i Wielinga, 1996; za Katsaros i Nikolaidis, 2012). Mimo tego, skale do pomiaru tolerancji wieloznaczności są często jednoczynnikowe (Katsaros i Nikolaidis, 2012).

Analiza oryginalnej skali Budnera do pomiaru tolerancji wieloznaczności wykazała, że mierzy ona 4 czynniki. Są to (Airlin i in. 1996): przewidywalność (np. „What we are used to is always preferable to what is unfamiliar”), różnorodność i oryginalność (np. „Often themost stimulating and interesting people are those who don't mind being different and original"); klarowność (np. „A good job is one where what is to be done and how it is to be done are always clear”), regularność (np. „People who fit their lives to a schedule probably miss most of the joy of living”). Te cztery czynniki odpowiadały za ponad połowę wariancji w badaniu (Airlin i in. 1996). 
Chociaż badacze wykazują zainteresowanie tolerancją wieloznaczności od pierwszej połowy XX wieku, nie udało się stworzyć adekwatnej metody do jej pomiaru (Norton, 1975), cechującej się wysoką trafnością i rzetelnością. Kirton, w swoim artykule z 1981 roku, wskazał, że skale do pomiaru tolerancji wieloznaczności mają dwie główne wady: nie są logicznie spójnymi operacjonalizacjami koncepcji tolerancji wieloznaczności oraz mają słabe wskaźniki psychometryczne (Kirton, 1981)

\section{Empiryczne korelaty tolerancji wieloznaczności}

Poziom tolerancji wieloznaczności danej osoby odgrywa rolę w każdej sytuacji, w której jest zbyt mało lub zbyt dużo informacji, lub gdy informacje są sprzeczne (Norton, 1975). Takich sytuacji, zwłaszcza społecznych, można wyobrazić sobie wiele. Oznacza to, że tolerancja wieloznaczności może być ważną zmienną w wielu obszarach, a skale mierzące ten konstrukt mają potencjalnie wiele zastosowań praktycznych.

Budner, w swoich badaniach, zainteresowany był pomiarem tolerancji wieloznaczności i jej związków w relacji z szerokim wachlarzem cech i zachowań mających znaczenie dla funkcjonowania społecznego (1962).

Ludzie różnią się stopniem akceptacji lub odrzucenia norm społecznych i powszechnie uznanych wartości. Dostosowanie się do obowiązujących norm pozwala na ustrukturalizowanie sytuacji i tym samym zmniejszenie liczby wieloznacznych bodźców. Można więc przypuszczać, że osoby z wyższym poziomem tolerancji wieloznaczności będą mniej konformistyczne i podporządkowane zewnętrznym regułom a także bardziej indywidualistyczne. W badaniach Budnera (1962) tolerancja wieloznaczności korelowała na poziomie 0,32 z tendencją do opisywania siebie jako osoby niekonwencjonalnej, $0,25 \mathrm{z}$ tendencją do opisywania siebie jako osoby lubiącej wyzwania i $0,27 \mathrm{z}$ tendencją do opisywania siebie jako osoby indywidualistycznej. Wszystkie korelacje były istotne na poziomie $\mathrm{p}=0,05$ (Budner, 1962).

Budner (1962) postawił także hipotezę mówiącą, że osoby o niskim poziomie tolerancji wieloznaczności będą charakteryzowały się większą religijnością i religijnym dogmatyzmem. Wiara w siły wyższe może być, podobnie jak konformizm, środkiem umożliwiającym redukowanie wieloznaczności. Hipoteza ta została potwierdzona tylko w pewnym zakresie. Uzyskane korelacje nie spełniły jednak przyjętego kryterium istotności $\mathrm{p}<0,05$.

Z poziomem tolerancji wieloznaczności związana okazała się być także częstotliwość, z jaką osoby rozważają sprawy wiary. Budner (1962) przewidywał, że jeśli bezkrytyczne przyjmowanie przekonań pozwala redukować wieloznaczność, to można zakładać negatywny 
związek takiej postawy z poziomem tolerancji wieloznaczności. Badania wykazały, że osoby o wyższym poziomie tolerancji wieloznaczności istotnie częściej oddawały się takim rozważaniom.

Budner (1962) zbadał także relację między tolerancją wieloznaczności a makiawelizmem, rozumianym jako „postawy i cechy osobowości zbieżne ze skutecznym manipulowaniem w relacjach interpersonalnych" (Budner, 1962, s. 42), mierzonym skalą Mach. Na 9 przebadanych grup, w 7 przypadkach uzyskano kierunek korelacji zgodny z zakładanym (związek dodatni). Trzy korelacje okazały się istotne statystycznie.

Zgodne z tymi danymi są także związki między tolerancją wieloznaczności a uległością wobec autorytetów. We wszystkich badanych grupach związki miały zakładany kierunek ujemny. Istotność statystyczną osiągnęło 6 z 9 korelacji.

Przedmiotem zainteresowania Budnera (1962) były także związki poziomu tolerancji wieloznaczności z wybieranym zawodem. W swoich badaniach skupił się na wyborze specjalizacji przez studentów medycyny. Poszczególne obszary medycyny różnią się stopniem ustrukturyzowania. Dziedziny ustrukturyzowane charakteryzuje relatywnie prosta diagnoza, terapia, sposób ewaluacji postępu terapii oraz jednoznaczny kontakt z pacjentem (Budner, 1962). Budner poprosił studentów medycyny o ocenę pięciu dziedzin podstawowych obszarów praktyki lekarskiej, z uwzględnieniem wymienionych kryteriów. Wyniki ułożyły się następująco: za najmniej ustrukturyzowaną dziedzinę studenci uznali psychiatrię, najbardziej chirurgię, oraz ginekologię i położnictwo. Pośrodku znalazły się: pediatria, praktyka ogólna (general practice) i interna (internal medicine). Uzyskane wyniki wskazują, że osoby z wyższym poziomem tolerancji wieloznaczności mają tendencję do wybierania mniej ustrukturowanych dziedzin. Osoby z niższym poziomem - bardziej utrukturyzowanych. Uzyskane korelacje nie spełniły jednak przyjętego kryterium istotności p $<0,05$.

Katsaros i Nikolaidis (2012) badali tolerancję wieloznaczności u greckich menadżerów z branży bankowej. Branża ta została przez nich wybrana jako cechująca się wysokim poziomem zmian, złożoności, nowości i szybkim rozwojem (Bank of Greece, 2011; Deloitte S.A, 2011; za: Katsaros i Nikolaidis, 2012). Według Kriegel'a i Brandt'a (1996; za: Katsaros i Nikolaidis, 2012), w obecnym, skomplikowanym środowisku biznesowym, tolerancja wieloznaczności może być kluczową cechą umożliwiającą szybkie i adekwatne reagowanie. Przegląd badań dokonany przez Katsaros'a i Nikolaidis'a (2012) wskazuje, że tolerancja wieloznaczności związana jest m.in. z satysfakcją z pracy, umiejętnością podejmowania decyzji, 
umiejętnością krytycznego myślenia i akceptacji ryzyka. Stwierdzono także, że menadżerowie z wysoką tolerancją wieloznaczności lepiej radzą sobie w nowych sytuacjach.

Zaskakująco, w badaniach Katsaros'a i Nikolaidis'a (2012), wynik pomiaru poziomu tolerancji wieloznaczności u greckich menadżerów z branży bankowej okazał się być niski. Autorzy wskazują, że na taki wynik mogła mieć wpływ raczej mało elastyczna kultura narodowa i biznesowa Greków oraz przywiązanie menadżerów sektora bankowego do konserwatywnych wartości.

Istotnym predyktorem poziomu tolerancji wieloznaczności u menadżerów okazało się być wewnętrzne lokowanie poczucia kontroli. Związek ten znajduje potwierdzenie także w innych badaniach (por. Mamlin i in. 2011; za: Katsaros i Nikolaidis, 2012). Innymi istotnymi predyktorami okazały się także: satysfakcja z pracy, poczucie ważności wykonywanej pracy oraz 3 zmienne demograficzne. Menadżerowie w wieku 35 - 44 lat (1), którzy nie pozostawali w stałych związkach (2) oraz posiadali wykształcenie magisterskie lub doktorat (3), mieli tendencję do wyższego poziomu tolerancji wieloznaczności.

\section{Skala Tolerancji Wieloznaczności: charakterystyka oryginalnego narzędzia}

McQuarrie i Mick - autorzy oryginalnej Skali Tolerancji Wieloznaczności, potrzebowali do przeprowadzenia własnego badania metody do pomiaru poziomu tolerancji wieloznaczności. Istniejące i opublikowane skale okazały się nieodpowiednie do ich celu z trzech powodów: skale te miały niską rzetelność, były zbyt długie lub ich zawartość była zbyt heterogeniczna (McQuarrie i Mick., 1992). Z tego powodu, podjęli się konstrukcji własnego narzędzia do pomiaru tolerancji wieloznaczności.

Do utworzenia Skali Tolerancji Wieloznaczności McQuarrie i Mick wykorzystali pozycje zaczerpnięte $\mathrm{z}$ trzech opublikowanych wcześniej skal do pomiaru tolerancji wieloznaczności (Budner 1962; MacDonald 1970; Norton 1975; za: McQuarrie i in., 1992). Wybrano twierdzenia, które pojawiły się w co najmniej jednej ze skal. W ten sposób otrzymano skalę składającą się z 20 itemów. Skalą przebadano grupę 118 osób. Współczynnik rzetelności alfa Cronbacha, dla tej 20 itemowej skali, wyniósł 0,64. Po wyeliminowaniu pozycji z interkorelacją poniżej 0,15 , skala liczyła 12 pozycji i osiągnęła alfa Cronbacha 0,7. Nie opublikowano dokładnych danych dotyczących walidacji skali. Autorzy nie podają także informacji o strukturze czynnikowej utworzonej przez nich Skali Tolerancji Wieloznaczności. W badaniach Phillips (2000, 2002; za: Bruner i in., 2005) skala osiągnęła alfa Cronbacha 0,67. 
Autorzy adaptowanej tutaj Skali Tolerancji Wieloznaczności nie opublikowali żadnych danych na temat struktury czynnikowej ich narzędzia. Obliczanie wyniku odbywa się przez sumowanie punktów za poszczególne odpowiedzi. W ten sposób uzyskuje się wynik ogólny skali. Wskazuje to, że badacze zakładali jednoczynnikową strukturę tolerancji wieloznaczności oraz jej addytywną naturę.

\section{Hipotezy}

Na podstawie przeglądu literatury wybrano cztery zmienne, które posłużą do zbadania trafności teoretycznej Skali Tolerancji Wieloznaczności. Sformułowano następujące hipotezy główne.

H1. Tolerancja wieloznaczności jest dodatnio związana z otwartościa na doświadczenie.

Charakterystyka osoby z wysoką tolerancją wieloznaczności obejmuje także cechy, którymi można opisać osobę otwartą na doświadczenie. Otwartość na doświadczenie (lub po prostu Otwartość) to jeden z czynników osobowości według modelu Wielkiej Piątki (McCrae i Costa, 1990; za: Garcia i in., 2005). McCrae i Costa opisują go jako „otwartość na nowe idee, podejścia (approaches) i doświadczenia." (McCrae i Costa, 1990; p. 41-42; za: Garcia i in., 2005). Oba konstrukty przejawiają się, m.in. preferencją nowości, ciekawością intelektualną oraz odczuwaniem przyjemności płynącej z poszukiwania nowości (Costa i McCrae, 1992b; za Garcia i in., 2005). Zarówno osoba otwarta na doświadczenie, jak i osoba o wysokim poziomie tolerancji wieloznaczności, mają tendencję do myślenia dywergencyjnego. Postawiono hipotezę mówiącą o pozytywnym związku tolerancji wieloznaczności z otwartością na doświadczenie.

H2. Tolerancja wieloznaczności jest ujemnie zwiąana z lękiem jako cechą.

Lęk jako cecha przejawia się tendencją do spostrzegania sytuacji jako zagrażających i odczuwania zwiększonego poziomu lęku (Spielberger, 1972). Sytuacje wieloznaczne mogą być odbierane przez osoby o wysokim poziomie lęku jako cechy jako zagrażające, z racji nowości, złożoności i sprzeczności, które je charakteryzują. Osoby o niskim poziomie tolerancji wieloznaczności odczuwają dyskomfort w obliczu sytuacji wieloznacznej. Można zakładać, że osoby o wysokim poziomie lęku jako cechy będą unikały sytuacji wieloznacznych i reagowały zwiększonym poziomem lęku, kiedy się w takich znajdą. Postawiono hipotezę mówiącą o negatywnym związku tolerancji wieloznaczności z lękiem jako cechą. 
H3. Tolerancja wieloznaczności jest ujemnie związana z bezdecyzyjnością.

Bezdecyzyjność, rozumiana jako zgeneralizowany wzorzec trudności w podejmowaniu decyzji (Osipow, 1999), często wiązana jest z lękiem przed popełnieniem błędu (Frost i Shows, 1993). Osoby bezdecyzyjne dostrzegają zbyt wiele sposobów na skategoryzowanie sytuacji (Rassin i Murris, 2005). Nie są zdolne tolerować braku kontroli oraz niepewności. Szybkie podejmowanie decyzji możliwe jest u osób bezdecyzyjnych jedynie w sytuacji, kiedy mają pewność, że decyzja jest wolna od błędu (Frost i Shows, 1993). Ponieważ sytuacje wieloznaczne są nieustrukturyzowanie i mają potencjalnie wiele rozwiązań, mogą wyzwalać lęk u osób bezdecyzyjnych. Postawiono hipotezę o negatywnym związku tolerancji wieloznaczności z bezdecyzyjnością.

H4. Tolerancja wieloznaczności jest ujemnie zwiazana z potrzeba poznawczego domknięcia.

Webster i Kruglanski (1989: za Czernatowicz-Kukuczka i in., 2014) definiują potrzebę poznawczego domknięcia jako potrzebę uzyskania szybciej i jednoznacznej odpowiedzi oraz awersję wobec niepewności. Tak zdefiniowana potrzeba poznawczego domknięcia jest sprzeczna $\mathrm{z}$ charakterystyką osoby o wysokim poziomie tolerancji wieloznaczności, która preferuje i poszukuje wieloznaczności oraz odczuwa w związku z nią przyjemność. Potrzeba poznawczego domknięcia przejawia się także tendencją do preferencji ustrukturyzowanych sytuacji oraz do redukowania złożoności przez posługiwanie się schematami i heurystykami myślenia. Nietolerancja wieloznaczności jest jedną ze składowych potrzeby poznawczego domknięcia (Kossowska, 2003). W badaniach Kossowskiej (2003) potrzeba poznawczego domknięcia okazała się istotnie korelować dodatnio z nietolerancją na wieloznaczność. Postawiono hipotezę o negatywnym związku tolerancji wieloznaczności z potrzebą domknięcia poznawczego.

Postawiono także dodatkowe hipotezy dotyczące związków tolerancji wieloznaczności z wybranymi danymi demograficznymi. Analiza różnic międzygrupowych zakłada przede wszystkim zbadanie związku poziomu tolerancji wieloznaczności z wykształceniem. Nauki ścisłe i humanistyczne różnią się stopniem ustrukturyzowania. Zakłada się, że osoby z wykształceniem ścisłym (grupa studentów reżyserii i akustyki dźwięku) mają istotnie mniejszy średni poziom tolerancji wieloznaczności niż osoby z wykształceniem humanistycznym (grupa studentów psychologii). W badaniu uwzględniono także profil klasy ukończonej w szkole średniej oraz poziom wykształcenia rodziców.

Pozostawanie w stałym związku wybrano jako wskaźnik funkcjonowania społecznego osoby. Relacje miłosne są w niewielkim stopniu ustrukturyzowane i jednoznaczne. Nawet, 
jeśli można wskazać pewne zasady, na których opiera się związek (patrz Willi, 2012), to stanowią one jedynie pewne ramy, w których para może rozwijać swoją relację. Nie gwarantują one jeszcze satysfakcjonującego związku. Postawiono hipotezę, że osoby w stałych związkach mają wyższy średni poziom tolerancji wieloznaczności, niż osoby niepozostające w związkach.

Badanie dotyczące płci i wieku ma charakter eksploracyjny.

\section{Badania własne}

\section{Procedura adaptacji}

Analiza pozycji oryginalnej skali wskazuje, że konstrukt tolerancji wieloznaczności jest uniwersalny kulturowo. Poziom tolerancji wieloznaczności można zmierzyć u każdej osoby, niezależnie od jej kultury pochodzenia. Poszczególne kultury mogą różnić się średnim poziomem tolerancji wieloznaczności w populacji.

W celu stworzenia polskiej wersji skali posłużono się strategią translacji (Drwal, 1995; za: Siuta, 2006). Strategia ta polega na przetłumaczeniu oryginalnego narzędzia, z wprowadzaniem zmian językowych tylko tam, gdzie dosłowny przekład nie jest możliwy.

Po przetłumaczeniu skali na język polski poproszono osobę biegle posługującą się językiem angielskim i polskim (posługującą się językiem angielskim jako pierwszym językiem) o dokonanie tłumaczenia wstecznego. Analiza różnic między oryginałem a tłumaczeniem wstecznym pozwoliła na przygotowanie ostatecznej wersji językowej skali.

\section{Metody}

W badaniach własnych uwzględniono badanie teoretycznego aspektu trafności. Wybrano 3 metody służące do badania trafności teoretycznej. Są to: analiza macierzy korelacji, analiza różnic międzygrupowych oraz analiza czynnikowa. Do analizy macierzy korelacji wybrano następujące zmienne: otwartość na doświadczenie (aspekt zbieżny trafności) oraz lęk jako cecha, bezdecyzyjność i potrzeba poznawczego domknięcia (aspekt różnicowy trafności). Do analizy różnic międzygrupowych wybrano następujące zmienne: eksploracyjna 
analiza czynnikowa w celu znalezienia innego, być może bardziej adekwatnego modelu czynnikowego. W celu oszacowania rzetelności skali wykorzystano współczynnik alfa Cronbacha.

Poza Skalą Tolerancji Wieloznaczności, w badaniach własnych użyto następujących metod:

\section{NEO-PI- R skala Otwartość na doświadczenie}

Otwartość na doświadczenie to jedna ze skal inwentarza osobowości NEO- PI-R, będącego adaptacją narzędzia opracowanego przez Costę i McCrae, opartego na teorii Wielkiej Piątki. Skala ta składa się z 48 pozycji. Odpowiedzi udzielane są na pięciopunktowej skali od 1 - całkowicie się zgadzam do 5 - całkowicie się nie zgadzam. Skala Otwartość na doświadczenie jest wielowymiarowa. Czynniki, które wchodzą w jej skład, to: estetyka, uczucia, działania, idee oraz wartości. Rzetelność skali Otwartość na doświadczenie, podawana przez autora polskiej wersji kwestionariusza NEO-PI- R (Siuta, 2006), wyrażona współczynnikiem alfa Cronbacha, wynosi 0,86. Rzetelności dla poszczególnych czynników Otwartości na doświadczenie wynoszą od 0,51 do 0,67 . Ocena struktury czynnikowej całego inwentarza NEO-PI-R oraz uzyskanych współczynników alfa Cronbacha, pozwala stwierdzić zadowalające podobieństwo do oryginalnej wersji narzędzia (Siuta, 2006). Otwartość na doświadczenie (obok Neurotyczności) jest skalą o najwyższej rzetelności spośród skal NEO- PI-R (Siuta, 2006). W badaniach własnych skala osiągnęła rzetelność alfa Cronbacha 0,86.

\section{STAI, arkusz X2}

STAI to szeroko wykorzystywana skala do pomiaru lęku jako stanu (podskala X1) i lęku jako cechy (podskala X2). Do badania własnego wykorzystano tylko podskalę X2. Zawiera ona 20 pozycji. Odpowiedzi udzielane są na czterostopniowej skali rozciągającej się od „prawie nigdy” do ,prawie zawsze”.

Anglojęzyczna wersja skali posiada bardzo dobre właściwości psychometryczne. Średnia korelacja w badaniu rzetelności metodą test - retest dla różnych interwałów czasowych wynosi $r=0,88$ (Gros $i$ in., 2007). Udowodniono także adekwatną trafność zbieżną i rożnicową skali (Gros i in., 2007). Mimo mocnych wskaźników rzetelności i trafności skala jest krytykowana za brak różnicowania między symptomami lęku i depresji oraz strukturę składającą się z dwóch czynników: "obecność lęku” i „brak lęku” (Gros i in., 2007). W badaniach własnych skala osiągnęła rzetelność alfa Cronbacha 0,9. 


\section{Skala Bezdecyzyjności}

Skala bezdecyzyjności zawiera 15 twierdzeń, do których osoba badana ustosunkowuje się korzystając z 5 punktowej skali odpowiedzi rozciągającej się od: 1 - zdecydowanie nie zgadzam się do 5 - zdecydowanie zgadzam się. Anglojęzyczna wersja skali posiada wysoką rzetelność alfa Cronbacha 0.87 (Frost i Shows, 1993). Badania Frost'a i Shows (1993) wskazują także na satysfakcjonującą trafność skali. Kwestionariusz zawiera dwie podskale: 1) strach przed podejmowaniem decyzji i 2) przyjemność z podejmowania decyzji. W badaniach własnych skala osiągnęła rzetelność alfa Cronbacha 0,9.

\section{Skala Potrzeby Poznawczego Domknięcia wersja skrócona}

Pełna wersja Skali Potrzeby Poznawczego Domknięcia jest kwestionariuszem stosunkowo długim. Autorzy skróconej wersji (Kossowska i in., 2012) piszą, że powszechną praktyką stało się stosowanie w badaniach jedynie wybranych pozycji skali, bez podawania informacji o tym, które pozycje zostały wybrane i na podstawie jakich kryteriów. Skłoniło to Kossowską, wraz z zespołem, do przygotowania i walidacji psychometrycznej skróconej wersji Skali Potrzeby Poznawczego Domknięcia. Do ostatecznej wersji skali zdecydowano się włączyć 15 pozycji. Poza kryteriami psychometrycznymi o doborze decydowała także zgodność z wyborem dokonanym przez autorów anglojęzycznej skróconej wersji Skali Potrzeby Poznawczego Domknięcia (Roets i Van Hiel, 2010; za: Kossowska i in., 2012) oraz zakres treściowy (odrzucano pozycje pokrywające się treściowo). Stworzona w ten sposób skala ma strukturę dwuczynnikową. Według autorów, jeden z czynników wiernie oddaje motywacyjny charakter konstruktu stworzonego przez Kruglanskiego (1989; za: Kossowska i in., 2012), drugi odnosi się do poznawczego aspektu procesu domykania. „Analiza właściwości psychometrycznych nowej wersji skali wskazuje, że narzędzie to ma lepsze własności niż oryginalne (usunięto pozycje wprowadzające zakłócenia pomiaru). Posiada także satysfakcjonującą trafność kryterialną, na co wskazują identyczne korelacje nowej wersji skali z narzędziami do pomiaru podobnych konstruktów, w porównaniu do korelacji oryginalnej wersji skali PPD z tymi samymi narzędziami” (Kossowska i in., 2012, s. 96). W badaniach własnych skala osiągnęła rzetelność alfa Cronbacha 0,6. 


\section{Przebieg badań}

Osoby badane zostały poinformowane o pełnej anonimowości badań. Rozdano im arkusze z informacjami dotyczącymi badania oraz zgody na udział w badaniu. Dla zapewnienia anonimowości zgody nie wymagały podpisu, jako wiążącą traktowano zgodę ustną. Następnie poinformowano osoby badane o możliwości zrezygnowania z udziału w badaniu oraz możliwości zadawania pytań dotyczących badania, także po jego zakończeniu. Po uzyskaniu od osób badanych zgody rozdano kwestionariusze. Kolejność użytych narzędzi była następująca: 1) Skala Tolerancji Wieloznaczności, 2) NEO- PI -R, skala Otwartość na doświadczenie, 3) Kwestionariusz STAI, skala X2, 4) Skala Bezdecyzyjności, 5) Skala Potrzeby Poznawczego Domknięcia wersja skrócona. Na końcu osoby badane proszone były o wypełnienie ankiet z danymi demograficznymi.

Badania prowadzone były od maja do października 2014 roku. Obejmowały dwie grupy porównawcze. Pierwszą grupę stanowili studenci psychologii w trybie zaocznym (75 osób), drugą - studenci reżyserii dźwięku i akustyki w trybie stacjonarnym (52 osoby). Łącznie przebadano 127 osób. Wszystkie osoby badane były studentami Uniwersytetu im. Adama Mickiewicza w Poznaniu. Grupa badawcza składa się ze 101 kobiet (79,5\%) oraz 26 mężczyzn (20,5\%). Wiek osób badanych wynosił od 18 do 48 lat (średnia=24, 96. SD=6, 07). Najczęstszą wartością jest wiek 22 lat (22\%). Mediana wynosi 23. Całość grupy badanej stanowili studenci, a więc osoby z wykształceniem średnim lub wyższym.

Z powodu niskich liczebności grup utworzonych z poszczególnych profili klas ukończonych przez osoby badane w szkole średniej, dane zostały rekodowane na 3 grupy: profil humanistyczny $(30,6 \%)$, ogólny $(12,6 \%)$ i ścisły $(56,8 \%)$. W skład profilu humanistycznego wchodzą klasy humanistyczna oraz językowa. W skład profilu ścisłego wchodzą następujące klasy: matematyczno - fizyczna, biologiczno - chemiczna, weterynaryjna, przyrodnicza, matematyczno - informatyczna, matematyczno - geograficzna, matematyczno - językowa oraz ekonomiczna. Profil ogólny składa się tylko z klasy o takim samym profilu.

W stałym związku znajdowało się 65 osób (52,8\%). Brak stałego związku zadeklarowało 58 osób $(47,2 \%)$.

Najczęstszym wykształceniem matek osób badanych jest wykształcenie wyższe (45,5\%). Wykształcenie średnie lub średnie techniczne ma 38\% matek osób badanych. Wykształcenie podstawowe lub zawodowe ma 16,5\% matek osób badanych. 
Najczęstszym wykształceniem ojców osób badanych jest wykształcenie wyższe (38,5\%). Wykształcenie średnie lub średnie techniczne ma 31,6\% ojców osób badanych. Wykształcenie podstawowe lub zawodowe ma 29,9\% ojców osób badanych

\section{Wyniki}

Pierwszym etapem statystycznej weryfikacji hipotez była analiza macierzy korelacji. Wszystkie hipotezy główne zostały potwierdzone. Korelacja tolerancji wieloznaczności z otwartością na doświadczenie (hipoteza 1) wyniosła $r$ Pearsona $=0,41$ i okazała się istotna na poziomie $\mathrm{p}<0,001$. Korelacja tolerancji wieloznaczności z lękiem jako cechą (hipoteza 1) wyniosła $r$ Pearsona $=-0,27$ i okazała się istotna na poziomie $p=0,003$. Korelacja tolerancji wieloznaczności z potrzebą poznawczego domknięcia wyniosła $r$ Spearmana=-0,46 i okazała się istotna na poziomie $\mathrm{p}<0,001$ (hipoteza 3). Korelacja tolerancji wieloznaczności z bezdecyzyjnością wyniosła $r$ Spearmana=-0,25 i okazała się istotna na poziomie $\mathrm{p}=0,005$ (hipoteza 4).

Drugim etapem była weryfikacja hipotez o związkach tolerancji wieloznaczności z danymi demograficznymi.

Przynależność do grupy studentów psychologii (średni wynik Skali Tolerancji Wieloznaczności STW=44,97) lub reżyserii dźwięku i akustyki (średni wynik STW=44,47) okazała się nie różnicować istotnie poziomu tolerancji wieloznaczności ( $\mathrm{t}=0,322, \mathrm{p}=0,748)$. Nie wykazano również istotnych różnic w poziomie tolerancji wieloznaczności między osobami będącymi w stałym związku (średni wynik STW=43,14) a osobami nie będącymi w stałym związku (średni wynik $\mathrm{STW}=45,16)(\mathrm{t}=0,604, \mathrm{p}=0,55)$. Także płeć okazała się nie różnicować poziomu tolerancji wieloznaczności. Średni wynik STW w grupie kobiet wynosi 45,06, w grupie mężczyzn 43,65. Wynik testu $t$ równości średnich wynosi $\mathrm{t}=0,483$ i nie jest istotny statystycznie $(\mathrm{p}=0,483)$. Analizy wariancji dla klasyfikacji ze względu na profil klasy $(\mathrm{F}=1,535, \mathrm{p}=0,154)$, wykształcenie matki $(\mathrm{F}=1,535, \mathrm{p}=0,154)$ oraz wykształcenie ojca ( $F=0,149, p=0,963)$, nie osiągnęły istotności statystycznej. Nieistotna okazała się także korelacja tolerancji wieloznaczności z wiekiem ( $\mathrm{r}$ Spearmana $=0,13, \mathrm{p}=0,15$ ).

Następnie wykonano analizę czynnikową w modelu eksploracyjnym, w celu sprawdzenia zgodności ze strukturą opisaną przez Budnera (Airlin i in. 1996), zawierającą 4 czynniki: przewidywalność, klarowność, regularność, różnorodność i oryginalność.

Analiza czynnikowa z uwzględnieniem rotacji VARIMAX oraz z wymuszonymi 4 czynnikami wykazała, że 4 czynniki wyjaśniają łącznie 60,4\% wariancji. Na czynniki 1 i 2 składają się 
po 4 pozycje. Czynnik 3 składa się z 3 pozycji, w skład czynnika 4 wchodzi zaledwie 1 pozycja. Analiza treściowa pozycji wchodzących w skład poszczególnych czynników wskazuje, że wyodrębnione w badaniu czynniki nie są zgodne z opisanymi przez Budnera (Airlin i in., 1996).

Dokonano także analizy czynnikowej z wymuszonymi kolejno 3 i 2 czynnikami. Włączenie pozycji nr 1 do czynnika 3 okazało się obniżać wyjaśnianą wariancję do 51,5\%. W przypadku struktury 2 czynnikowej wyjaśniana wariancja wynosi $42 \%$. Za każdym razem dokonywano analizy treściowej pozycji wchodzących w skład wymienionych czynników. Zarówno podział na 3, jak i 2 czynniki, nie wyłania jednorodnych treściowo podskal. Z punktu widzenia uzyskanych w badaniu wyników Skala Tolerancji Wieloznaczności wydaje się być narzędziem jednoczynnikowym.

Do badania rzetelności skali użyto współczynnika alfa Cronbacha. Skala Tolerancji Wieloznaczności osiągnęła alfa Cronbacha równe 0,68. Usunięcie ze skali pozycji trzeciej spowodowałoby wzrost rzetelności do poziomu alfa Cronbacha równe 0,7. Korelacje poszczególnych pozycji z wynikiem ogólnym przedstawia Tabela 1.

Tabela 1. Współczynniki mocy dyskryminacyjnej pozycji.

\begin{tabular}{|c|c|c|}
\hline & $\begin{array}{l}\text { Współczynnik mocy } \\
\text { dyskryminacyjnej }\end{array}$ & $\begin{array}{l}\text { Alfa Cronbacha po } \\
\text { usunięciu pozycji }\end{array}$ \\
\hline STW1 &, 269 &, 663 \\
\hline STW2 &, 418 &, 640 \\
\hline STW3 &, 091 & ,697 \\
\hline STW4 &, 281 & ,661 \\
\hline STW5 & ,364 & ,647 \\
\hline STW6 & 197 &, 674 \\
\hline STW7 &, 300 & ,658 \\
\hline STW8 &, 423 & ,637 \\
\hline STW9 & 334 &, 653 \\
\hline STW10 &, 254 & ,665 \\
\hline STW11 & ,414 & ,641 \\
\hline STW12 &, 459 & ,633 \\
\hline
\end{tabular}




\section{Dyskusja}

Potwierdzenie w badaniach własnych znalazły wszystkie hipotezy główne. Wysoki poziom tolerancji wieloznaczności związany jest istotnie z wysokim poziomem otwartości na doświadczenie. Uzyskana korelacja potwierdza teoretyczną bliskość obu konstruktów. Wysoki poziom tolerancji wieloznaczności jest także istotnie związany z niskim lękiem jako cechą, bezdecyzyjnością i potrzebą domknięcia poznawczego. Uzyskane korelacje potwierdzają teoretyczną odległość tych konstruktów i pewien stopień sprzeczności ich charakterystyk. Wartość bezwzględna uzyskanych korelacji waha się od 0,25 do 0,46 . Analiza macierzy korelacji dostarcza wstępnych danych potwierdzających trafność teoretyczną Skali Tolerancji Wieloznaczności.

Nie znalazła potwierdzenia żadna z hipotez dodatkowych. Rodzaj studiów (humanistyczne lub ścisłe) nie okazał się być związany z poziomem tolerancji wieloznaczności. Wynik ten nie potwierdza hipotezy Budnera (1962) mówiącej, że poziom tolerancji wieloznaczności związany jest z wyborem ścieżki edukacji i kariery. Wskazać jednak należy na niejednorodność grup porównawczych, która mogła mieć wpływ na uzyskane wyniki. W grupie studentów psychologii w trybie zaocznym ( średnia 27,28; SD=6,90) wiek osób badanych jest bardziej zróżnicowany niż w grupie studentów reżyserii dźwięku i akustyki w trybie stacjonarnym (średnia 22; $\mathrm{SD}=3,10$ ). Grupa studentów psychologii jest także mniej jednorodna pod względem wykształcenia. Więcej osób w tej grupie ukończyło inny kierunek studiów i posiada wykształcenie magisterskie. Zebrane na ten temat dane nie są jednak wystarczające do analizy. Hipoteza dotycząca związku poziomu tolerancji wieloznaczności z wybieranym zawodem (przewidywano wysoki poziom tolerancji wieloznaczności u menadżerów z branży bankowej) nie znalazła potwierdzenia także w badaniach Katsaros'a i Nikolaidis'a (2012). Być może pomiędzy poziomem tolerancji wieloznaczności a wybieraną ścieżką kariery znajduje się jakaś zmienna (lub zmienne) pośrednicząca. Z poziomem tolerancji wieloznaczności nie jest związany także profil klasy ukończonej w liceum oraz poziom wykształcenia rodziców. Nie znalazła potwierdzenia także hipoteza o związku poziomu tolerancji wieloznaczności z wiekiem. Korelacja ta nie osiągnęła wymaganego poziomu istotności. Rozkład wieku w grupie badawczej nie był zgodny z rozkładem normalnym. Istnieje prawdopodobieństwo, że w badaniach przeprowadzonych na reprezentatywnej próbie korelacja ta okazałaby się istotna. Pozostawanie w stałym związku nie różnicuje wyników Skali Tolerancji Wieloznaczności. 
Zmienna ta nie sprawdziła się jako wskaźnik funkcjonowania w sytuacjach społecznych i relacjach miłosnych, które jak zakładano, często cechuje wieloznaczność.

Mimo teoretycznego uzasadnienia złożonej struktury skal do pomiaru tolerancji wieloznaczności (Benjamin i in. 1996; za Katsaros i Nikolaidis, 2012) i empirycznie wyodrębnionych czynników skali Budnera (Airlin i in., 1996), najbardziej adekwatna w przypadku Skali Tolerancji Wieloznaczności wydaje się być struktura jednoczynnikowa, zgodna ze strukturą oryginalnej wersji skali. Podział na 4, 3 i 2 czynniki nie wyłania jednorodnych pod względem treściowym podskal.

Polska adaptacja Skali Tolerancji Wieloznaczności (alfa Cronbacha 0,68) osiągnęła rzetelność zbliżoną do uzyskanej przez autorów oryginalnej skali (alfa Cronbacha 0,7) a także do uzyskanej przez Phillips (2000, 2002; za: Bruner i in., 2005) (alfa Cronbacha 0,67). Rzetelność skali jest stosunkowo niska. Skala w obecnej formie znajduje się na granicy akceptowalności. Przy adaptacji skali nie udało się rozwiązać problemu słabych wskaźników psychometrycznych skal do pomiaru tolerancji wieloznaczności, o którym pisze Kirton (1981). Z tego względu głównym zastosowaniem skali są badania naukowe.

Uzyskane w badaniach własnych dane wskazują, że Skala Tolerancji Wieloznaczności jest trafna teoretycznie. Pomiar skalą umożliwia umieszczenie osoby na kontinuum tolerancji wieloznaczności. Wykazano, że osoba z wysokim poziomem tolerancji wieloznaczności na ogół cechuje się także ciekawością intelektualną, poszukiwaniem nowości, liberalnością wyznawanych wartości, niską tendencją do spostrzegania sytuacji jako zagrażających i reagowania na nie lękiem oraz niską potrzebą podejmowania szybkich i jednoznacznych decyzji.

Nie opublikowano do tej pory żadnych innych danych dotyczących walidacji skali, dlatego też wyniki te należy traktować jako wstępne. Pożądane są kolejne badania walidacyjne, które pozwolą na dokładniejsze określenie obszarów zastosowania skali i rewizję teorii konstruktu tolerancji wieloznaczności.

\section{Literatura cytowana:}

Airlin, J. B. Jr., Riggio, R. E., Mayes, B. T. (1996). Reliability and Factor Structure of Budner's Tolerance for Ambiguity Scale. Journal of Social Behavior and Personality, 11(3), 625 - 632.

Bruner, G. C., Hensel, P. J., James, K. E. (2005). Marketing Scales Handbook, Volume IV: Consumer Behavior. Chicago, Ill: American Marketing Association.

Budner, S. (1962). Intolerance of ambiguity as a personality variable. Journal of Personality, 30, 29 50 . 
Czernatowicz -Kukuczka, A., Jaśko, K., Kossowska, M. (2014). Need for closure and dealing with uncertainty in decision making context: The role of the behavioral inhibition system and working memory capacity. Personality and Individual Differences, 70, 126 - 130.

Eysenck, H. J. (1954). The psyhology of politics (wyd. 2). New Brunswick: Transaction Publishers.

Frost, R. O., Shows, D. L. (1993). The Nature and Measurement of Compulsive Indecisiveness. Behavioral Research and Therapy. 31(7), $683-692$.

Garcia, L. F., Aluja, A., Garcia, O., Cuevas L. (2005).Is Openness to Experience an Independent Personality Dimension? Convergent and Discriminant Validity of the Openness Domain and its NEO-PI-R Facets. Journal of Individual Differences. 26(3), 132 - 138.

Gros, D. F., Martin, M. A., Simms, L. J., McCabe R. E. (2007) Psychometric Properties of the State-Trait Inventory for Cognitive and Somatic Anxiety (STICSA): Comparison to the State-Trait Anxiety Inventory (STAI). Psychological Assessment 19(4), 369 - 381.

Katsaros, K. K., Nicolaidis, C. S., (2012). Personal Traits, Emotions, and Attitudes in the Workplace: Their Effect on Managers' Tolerance of Ambiguity. The Psychologist Manager Journal, 15, 37 - 55.

Kirton, M. J. (1981). A Reanalysys of Two Scales of Tolerance of Ambiguity. Journal of personality assessment, 45(4), $407-414$.

Kossowska, M. (2003). Różnice indywidualne w potrzebie poznawczego domknięcia. Przegląd psychologiczny, 46(4), $355-373$.

Kossowska, M., Hanusz, K., Trejtowicz, M. (2012). Skrócona wersja Skali Potrzeby Poznawczego Domknięcia. Dobór pozycji i walidacja skali. Psychologia Społeczna, 1(20), 89 -99 .

MacDonald, A. P. Jr., (1970). Revised scale for ambiguity tolerance: reliability and validity. Psychological Reports, 26, $791-798$.

McQuarrie, E. F., Mick, D. G. (1992) On Resonance: A Critical Pluralistic Inquiry into Advertising Rhetoric. Journal of Consumer Reaserch 19, 180 - 197.

Norton, R. W. (1975). Measurement of Ambiguity Tolerance. Journal of personality assessment, 39(6), $607-617$.

Osipow, S. H., (1999). Assessing Career Indecision. Journal of Vocational Behavior, 55, 147 154.

Siuta, J. (2006). Inwentarz osobowości NEO -PI-R Paula T. Costy Jr i Roberta R. McCrae. Adaptacja polska. Podręcznik. Warszawa: Pracownia Testów Psychologicznych.

Spielberger, C. D., (1972). Anxiety as an emotional state. W: C. D. Spielberger (red.). Anxiety: Current Trends is Theory and Research (t. 1, s. 23 - 49). New York: Academic Press.

Willi, J. (2014). Zwiazek dwojga. Psychoanaliza pary. Warszawa: Oficyna Wydawnicza Fundament. 
Załącznik

\section{Skala Tolerancji Wieloznaczności}

\section{Instrukcja:}

Proszę uważnie przeczytać poniższe twierdzenia. Przy każdym zdaniu należy otoczyć kółkiem odpowiedź, w skali od: 1 -calkowicie się nie zgadzam, do: 7 -calkowicie się zgadzam, która najlepiej wyraża Pana/Pani opinię. Proszę się upewnić, czy swoją odpowiedź wpisuje Pan/Pani przy odpowiednim twierdzeniu. Proszę ustosunkować się do wszystkich twierdzeń. Jeżeli Pan/Pani się pomyli, należy wyraźnie przekreślić 1 pierwszą odpowiedź i zaznaczyć właściwą.

\begin{tabular}{|l|l|l|}
\hline 1. & Lubię filmy lub książki z wyraźnym, określonym zakończeniem. (r) & 1234567 \\
\hline 2. & Zawsze chcę wiedzieć z czego ludzie się śmieją. (r) & 1234567 \\
\hline 3. & Chciałbym żyć w obcym kraju przez jakiś czas. & 1234567 \\
\hline 4. & $\begin{array}{l}\text { Dobra praca to taka, w której zadania i sposób ich wykonania są zawsze } \\
\text { dobrze określone. (r) }\end{array}$ & 1234567 \\
\hline $\mathbf{5 .}$ & Lubię niejednoznaczną lub ukrytą symbolikę. & 1234567 \\
\hline $\mathbf{6 .}$ & Niepokoję się, kiedy nie mogę nadążyć za czyimś tokiem myślenia. (r) & 1234567 \\
\hline $\mathbf{7 .}$ & Dobrze czuję się w wieloznacznych sytuacjach & 1234567 \\
\hline $\mathbf{8 .}$ & Wiersz nigdy nie powinien zawierać sprzeczności. (r) & 1234567 \\
\hline $\mathbf{9 .}$ & $\begin{array}{l}\text { Niewyraźne, impresjonistyczne obrazy przemawiają do mnie bardziej } \\
\text { niż realistyczne. }\end{array}$ & 1234567 \\
\hline $\mathbf{1 0 .}$ & $\begin{array}{l}\text { Lubię pracować nad rozwiązaniem problemu, o ile jest możliwość uzy- } \\
\text { skania wyraźnej i jednoznacznej odpowiedzi. (r) }\end{array}$ & 1234567 \\
\hline $\mathbf{1 1 .}$ & Im więcej znaczeń ma wiersz, tym bardziej mi się podoba. & 1234567 \\
\hline $\mathbf{1 2 .}$ & $\begin{array}{l}\text { Bardziej lubię przyjęcia, na których znam większość ludzi, od tych, na } \\
\text { których większość ludzi jest mi obca. (r) }\end{array}$ & 1234567 \\
\hline
\end{tabular}

